\title{
Mechanical properties degradation in a Cr-Mo low-alloy steel pipe after prolonged use for gas transport in a power plant station ${ }^{(\bullet)}$
}

\author{
D. Mihai" and L.G. Bujoreanu**
}

\begin{abstract}
Some prolonged exposure effects at the high temperatures and pressures characteristic to the steam transport in power station, have been revealed in a 12HMF GOST (13CrMo44 DIN) Cr-Mo low alloy steel pipes, at both macro and microstructural level, by mechanical tests and optical microscopy. After 128625 functioning hours, a marked mechanical degradation was noticed by the values of tensile strength, hardness and toughness that decreased with $14-16 \%, 45-48 \%$ and $47-59 \%$, respectively. This lose of mechanical properties was correlated on one hand to the coalescence of ferrite grains and pearlite islets and on the other hand to a decrease in the anisotropy of the grains morphology.
\end{abstract}

Keywords Prolonged steam transport. Mechanical tests. Anisotropy. Optical micrographs. Carbide precipitation.

\section{Desgaste de las características mecánicas en las conducciones de acero Cr-Mo de baja aleación tras un uso prolongado en el transporte del vapor en una central térmica}

\begin{abstract}
Resumen
Se han determinado algunos efectos de la exposición prolongada a temperaturas y presiones altas, características del transporte del vapor en una central térmica, en las conducciones de acero 12HMF GOST (13CrMo44 DIN) Cr-Mo de baja aleación, a nivel macro y microestructural a través de ensayos mecánicos y microscopia óptica.Tras $128.625 \mathrm{~h}$ de servicio, se ha notado una notable degradación mecánica en los valores de la resistencia a la rotura, de la dureza y de la resilencia, que han disminuido entre un $14-16 \%$, un $45-48 \%$ y un $47-59 \%$, respectivamente. La degradación mecánica se correlacionó, por una parte, con la coalescencia de los granos de ferrita y de las islas de perlita y, por otra, con el decrecimiento en la anisotropía de la morfología de los granos.
\end{abstract}

Palabras clave Transporte prolongado del vapor. Ensayos mecánicos. Anisotropía. Micrografías ópticas. Precipitación de los carburos.

\section{INTRODUCTION}

High temperature-strength materials include engineering and porous ceramics, as well as some engineering alloys such as $\mathrm{Ni}$-alloys and $\mathrm{Ti}$-alloys. Excepting for porous ceramics, that have rather limited technical use, none of them are cheaper than steel ${ }^{[1]}$.

Among steels, Cr-Mo low-alloy steels are less expensive, weldable and creep resisting being used as steam pipe and superheating tubing for steam generation and power plants. These creep-resistant steels have a ferrite-pearlite microstructure; contain less than $0.25 \% \mathrm{C}$ and small additions of chromium and molybdenum ${ }^{[2]}$.

After prolonged use for "live steam" transport in power station, during which they were exposed at pressures and temperatures up to $19 \mathrm{MPa}$ and 540 ${ }^{\circ} \mathrm{C}$, respectively, $\mathrm{Cr}-\mathrm{Mo}$ low alloy steel pipes may experience marked lose of their mechanical characteristics ${ }^{[3]}$. Such mechanical degradation, after more than eight years of continuous functioning in a power station and additionally enhanced by the increase of test temperature above $500^{\circ} \mathrm{C}$, has been previously emphasized in the case of $15 \mathrm{HM}$ GOST (16CrMo4 DIN) steel pipes.

• Trabajo recibido el día 3 de diciembre de 2001 y aceptado en su forma final el día 22 de octubre de 2002.

$\left(^{*}\right)$ The "Gh. Asachi", Technical University of lasi, Faculty of Mechanical Engineering, Strength of Materials Department. Bd. D. Mangeron 59-61, 6600 lasi-Romania.E-mail:mdumitru@mec.tuiasi.ro

$\left({ }^{* *}\right)$ The "Gh. Asachi", Technical University of lasi, Faculty of Materials Science and Engineering, Metals Technology Department. Bd. D. Mangeron 63, 6600 lasi-Romania. E-mail: Igbujor@tuiasi.ro 
Besides a content of manganese, silicon, sulfur and phosphorus, ranging within the limits usually in plain carbon steels, this Russian Cr-Mo low-alloy steel contains: $(0.8-1.1) \% \mathrm{Cr},(0.4-0.55) \% \mathrm{Mo}$ and (0.12-0.18) \% ${ }^{[4]}$.

Similar long-lasting exposure effects were also observed at 15223 CSN Czech steel pipes, which served for steam transport during more than seven years ${ }^{[5]}$. When comparing the exposed state to the initial one, this steel - which is not actually of the Cr-Mo type - experienced much more pronounced decreases of mechanical characteristics on transversal than on longitudinal sections ${ }^{[6]}$.

The purpose of the present work is to evaluate the mechanical properties degradation, on both longitudinal and transversal sections of the pipes made from Russian low-alloyed $\mathrm{Cr}$-Mo steel 12HMF GOST (13CrMo44 DIN), caused by increasing continuing functioning in a power plant to more than fourteen years.

\section{EXPERIMENTAL PROCEDURE}

12HMF GOST (13CrMo44 DIN) steel samples were provided by a power station that has functioned continuously for at least twenty years. The steel has the chemical composition $0.12 \mathrm{C}$ $1.15 \mathrm{Cr}-0.22 \mathrm{Mo}-0.26 \mathrm{~V}-0.5 \mathrm{Mn}-0.32 \mathrm{Si}-0.0144$ P - $0.016 \mathrm{~S}$-bal. Fe (wt. \%). The pipes were manufactured by controlled rolling, performed between 1200 and $820^{\circ} \mathrm{C}$ in order to allow complete recrystallization and fine grain obtaining, followed by slow cooling in order to avoid formation of intermediary constituents. During programmed technical revisions, the samples were cut from different pipe sections, which had the initial dimensions: $865-\mathrm{mm}$ length, $273-\mathrm{mm}$ diameter and $36 \mathrm{~mm}$ wall thickness. These sections were permanently kept in function, excepting for accidental or technical revision stopping, for four different functioning times: 34898, 63706, 98619 and $128625 \mathrm{~h}$, representing about 4, 7, 11 and 14 years respectively. In addition, samples were cut, as well, from a spare pipe with 0 functioning hours, in initial (delivery) condition. In each of the above five cases the samples were taken with two different orientations: longitudinal and transversal.

From each of the ten samples, four types of specimens were machined for: (i) tensile tests, (ii) hardness tests, (iii) impact tests and (iv) optical metallographic observations, respectively. Great care was taken in order to preserve the original state of the material by avoiding overheating and hard mechanical shocks, which could alter its thermal and mechanical history. Standard round tensile specimens had a central cylindrical gauge $(\Phi 10 \times 70 \mathrm{~mm}$, according to EN 10002-1/1995), hardness specimens were flat cylindrical $(\Phi 50 \times 15$ $\mathrm{mm}$, according to 10003-1/1997), impact specimens were U-notched parallelepipedic $(55 \times$ $10 \times 10 \mathrm{~mm}^{3}$, according to EN 10045-1/1993) and metallographic specimens were parallelepipedic $\left(20 \times 36 \times 50 \mathrm{~mm}^{3}\right)$.

Tensile tests were performed with a strain rate of $5 \cdot 10^{-3} \mathrm{~s}^{-1}$ on a VEB $500 \mathrm{kN}$ tensile testing machine, Brinell hardness was determined by means of an universal hardness tester type AB-1, Charpy U-notch tests were carried out with an impact pendulum and metallographic observations were achieved, after suitable preparation of specimens, on a NEOPHOT 32 optical microscope. All the experiments were carried out at ambient temperature. On the recorded tensile stress-strain curves, yield and tensile strengths have been determined ${ }^{[7]}$.

\section{EXPERIMENTAL RESULTS AND DISCUSSION}

\subsection{Mechanical tests}

Figure 1 illustrates the ten tensile curves corresponding for the above five functioning periods, for both transversal (dotted line) and longitudinal (solid line) orientations of the specimens. Each curve has been plotted through at

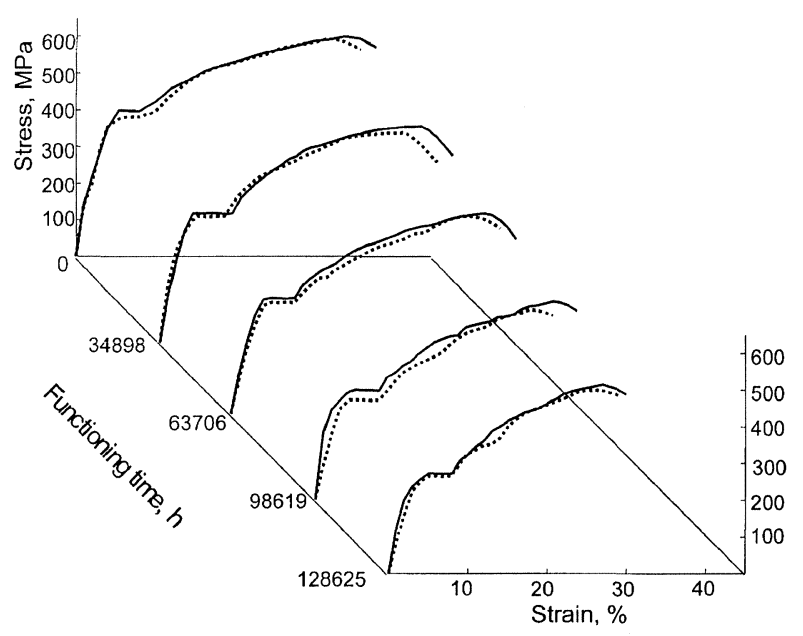

Figure 1. Influence of functioning time on the tensile curves of the transversal (dotted line) and longitudinal (solid line) specimens.

Figura 1. Influencia del tiempo en servicio sobre las curvas de tracción de las probetas transversales (línea punteada) y longitudinales (línea continua). 
least 40 points and each point represents the average of 5 tests. The measuring error has been \pm $3 \%$. With increasing the functioning period, the material becomes weaker and the stress-strain curves correspondingly fall towards lower stresses. In addition, ultimate strain also becomes more reduced.

The variation of yield stress with the functioning time is illustrated in figure 2. Two aspects are obvious: (i) yield stress decreased with the increasing the functioning time and (ii) in every case, higher values were determined for specimens with longitudinal orientation as compared to those with transversal orientation. This anisotropy effect has been caused by nonmetallic inclusions that were either elongated or broken into smaller fragments aligned along rolling direction according to their ductile or brittle character, respectively. This distribution of the second phase particles determines a small elongation of the grains along the rolling direction, and therefore the appearance of a weak texture component. This texture will causes the plastic anisotropy found in the chemical test. Yield stresss decreased from 381 and $399 \mathrm{MPa}$, at 0 functioning hours, to 266 and $271 \mathrm{MPa}$, at 128625 functioning hours, for specimens with transversal and longitudinal orientations, respectively.

The same aspects are noticeable from figure 3 that displays the tensile strength variations with the functioning time for the two orientations. In this case, tensile strengths ranged from 594 and $600 \mathrm{MPa}$, at 0 functioning hours, to 501 and 515 $\mathrm{MPa}$, at 128625 functioning hours, for specimens

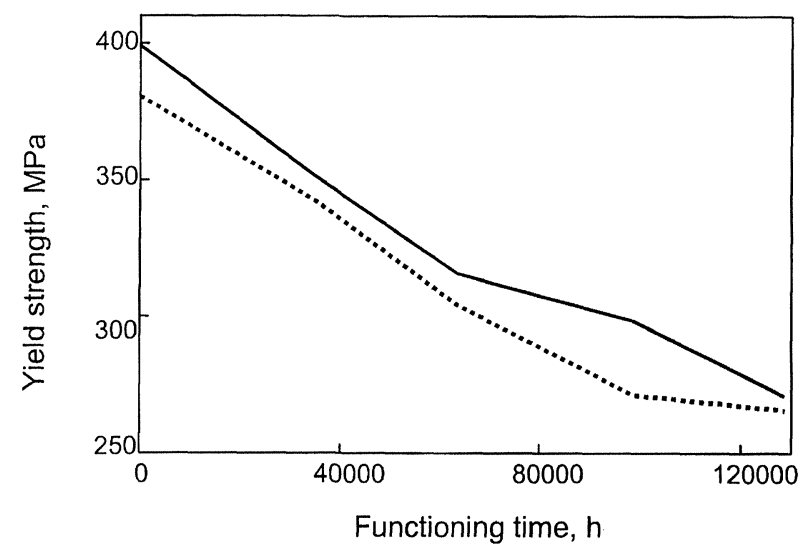

Figure 2. Yield strength variation with functioning time for specimens with transversal (dotted line) and longitudinal (solid line) orientation.

Figura 2. Variación del límite elástico con el tiempo en servicio para las probetas transversales (linea punteada) y longitudinales (línea continua).

\section{6}

(c) Consejo Superior de Investigaciones Científicas

Licencia Creative Commons 3.0 España (by-nc)

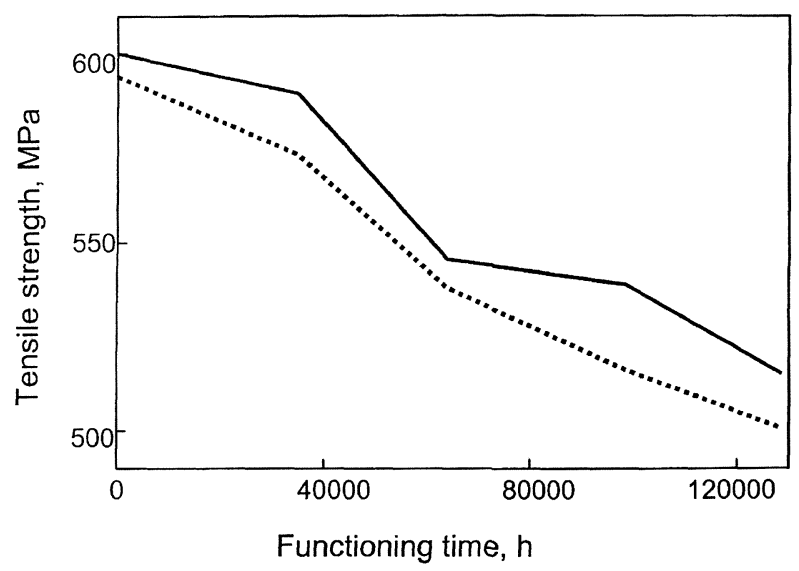

Figure 3. Tensile strength variation with functioning time for specimens with transversal (dotted line) and longitudinal (solid line) orientation.

Figura 3. Variación de la resistencia a la tracción con el tiempo en servicio para las probetas transversales (línea punteada) y longitudinales (línea continua).

with transversal and longitudinal orientations, respectively.

As far as Brinell hardness is concerned, its values have decreased from 158 and $161 \mathrm{daN} / \mathrm{mm}^{2}$, in initial state, to 83 and $89 \mathrm{daN} / \mathrm{mm}^{2}$, after 128625 functioning hours, for transversal and longitudinal orientations, respectively. The corresponding hardness variation, displayed in figure 4 , is similar to the yield stress variation shown in figure 2 .

Finally, the values of the energy absorbed during Charpy U-notch test are illustrated as a function of time for the two orientations in figure 5. Absorbed

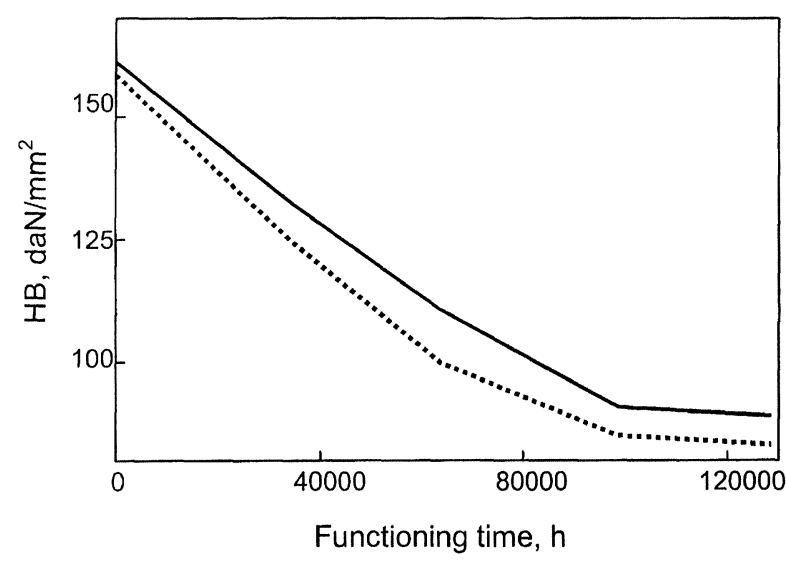

Figure 4. Brinell hardness variation with functioning time for specimens with transversal (dotted line) and longitudinal (solid line) orientation.

Figura 4. Variación de la dureza Brinell con el tiempo en servicio para probetas transversales (línea punteada) y longitudinales (línea continua).

Rev. Metal. Madrid 38 (2002) 464-468 


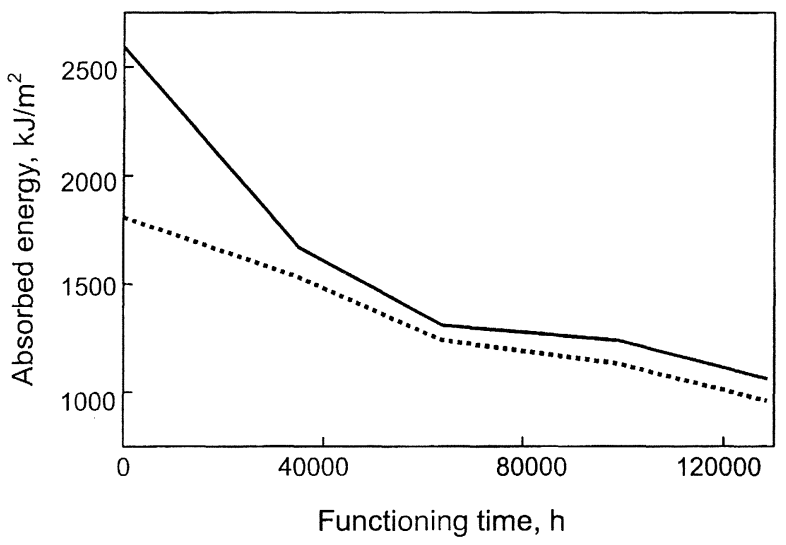

Figure 5. Variation of the absorbed energy, during the Charpy U-notch impact test, with functioning time for specimens with transversal (dotted line) and longitudinal (solid line) orientation.

Figura 5. Variación de la energía absorbida en un ensayo Charpy con entalla en $U$, con el tiempo en servicio para las probetas transversales (línea punteada) y longitudinales (linea continua).

energy decreased from 1808 and $2590 \mathrm{~kJ} / \mathrm{m}^{2}$, in initial condition, down to 960 and $1060 \mathrm{~kJ} / \mathrm{m}^{2}$, after 128625 functioning hours, for transversal and longitudinal orientations, respectively. The large difference $\left(782 \mathrm{~kJ} / \mathrm{m}^{2}\right)$ between absorbed energies along longitudinal and transversal direction in initial state could be ascribed to the preferred alignment of carbides along the rolling direction. As the fracture surface is perpendicular to the direction along which the sample was machined, carbide alignment would determine that the number of grain boundaries per length unit will be larger along longitudinal direction. This point is equivalent to a material with a lower grain size and it would be accompanied by an increase in the toughness.

\subsection{Optical microscopy metallographic obser- vations}

Figure 6 presents a typical optical micrograph of the specimen with transversal orientation, in initial condition ( 0 functioning hours). The microstructure comprises polyhedral ferrite grains and small isolated pearlite islets. Due to the low amount of carbide-forming elements few carbides are noticeable either inside the grains or along the grain boundaries.

The microstructure shown in figure 7 is representative for the longitudinal orientation of the specimen in initial state and for this reason it is quite similar to figure 6 . However, as an effect of

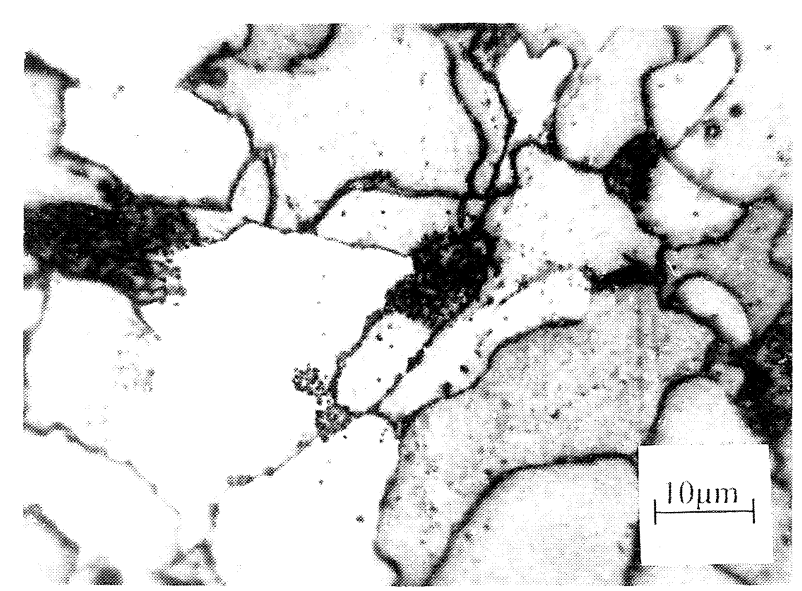

Figure 6. Typical optical micrograph of a cross section of a specimen in initial condition.

Figura 6. Micrografía óptica típica de una sección transversal de una probeta en estado inicial.

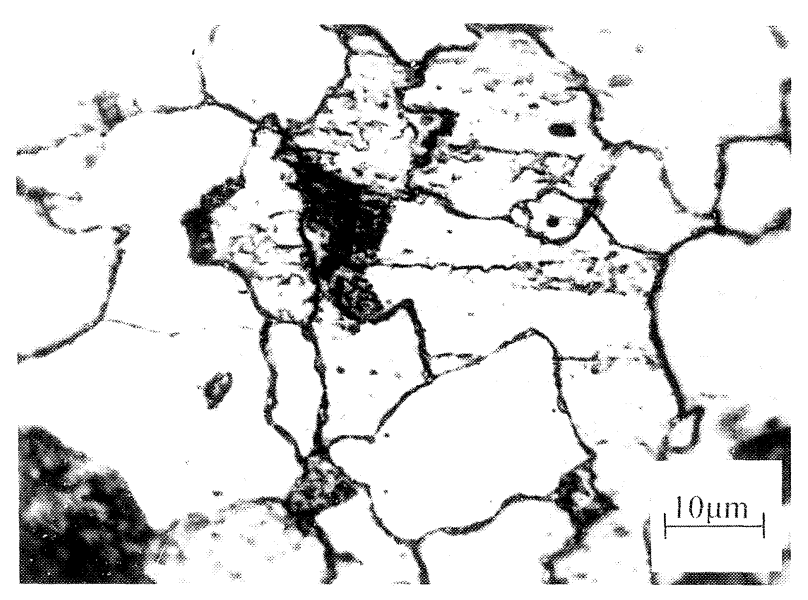

Figure 7. Typical optical micrograph along the rolling direction of a specimen in initial condition.

Figura 7. Micrografía óptica típica a lo largo de la dirección de laminación de una probeta en estado inicial.

hot rolling, the carbides present in the microstructure are grouped in band along rolling direction.

The microstructural effects of 128625 functioning hours, within the "live" steam tubing, on the typical micrograph of a specimen with transversal orientation, are shown in figure 8. It is obvious that, after more than fourteen years of thermomechanical loading, some irreversible changes occurred. Firstly, both ferrite grains and pearlite islets coalesced as compared to delivery state. Secondly, an increase of equiaxiality of grains has been noticeable. These microstructural changes could provide a good explanation for the marked degradation of mechanical characteristics, 
Mechanical properties degradation in a Cr-Mo low-alloy steel pipe after prolonged use for gas transport in a power plant station D. MiHAI AND L.G. BUJOREANU

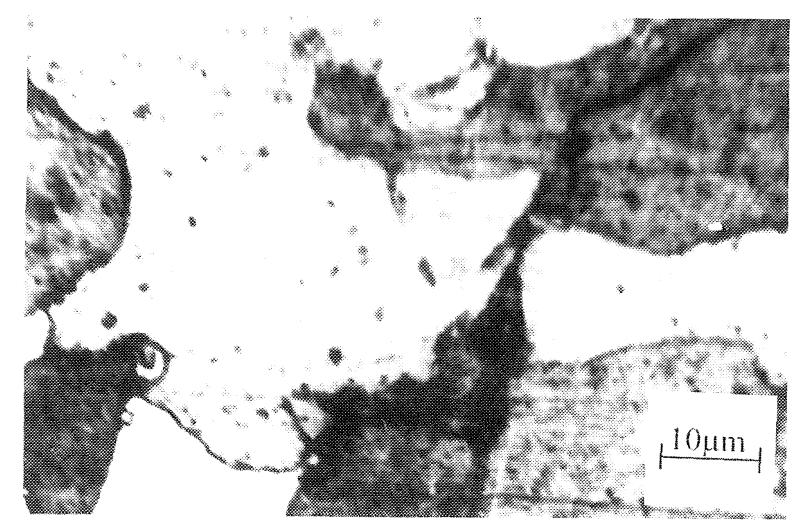

Figure 8. Typical optical micrograph of a cross section of a specimen after 128625 functioning hours.

Figura 8. Micrografía óptica típica de una sección transversal de una probeta sometida a $128625 \mathrm{~h}$ de servicio.

which was observed on specimens with transversal orientation.

The microstructural changes caused by prolonged exposure to elevated temperatures and pressures, at the specimens with longitudinal orientation, are illustrated in figure 9. Ferrite grains and pearlite islets are basically similar to those found in figure 8 , for transversal orientation.

\section{CONCLUSIONS}

12HMF GOST (13CrMo44 DIN) steel pipes, which were used for "live" steam transport during increasing functioning periods, up to $128625 \mathrm{~h}$, experienced two microstructural irreversible changes: (i) coalescence of ferrite grains and pearlite islets and (ii) increase of equiaxiality which corresponds to an anisotropy decrease. These changes could be responsible for the pronounced degradation of some mechanical characteristics and for the anisotropy decrease as far as toughness is involved. After 128625 functioning hours, tensile strength decreased with 14-16\%, Brinell hardness with 45-48 \% and

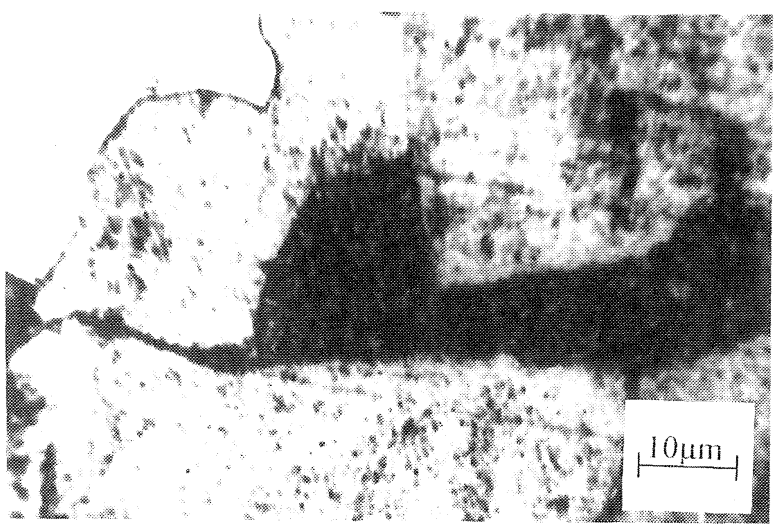

Figure 9. Typical optical micrograph along the rolling direction of a specimen after 128625 functioning hours.

Figura 9. Micrografía óptica típica a lo largo de la dirección de laminación de una probeta sometida a $128625 \mathrm{~h}$ en servicio.

absorbed energy during Charpy U-notch impact test with $47-59 \%$, as compared to initial (delivery) state.

\section{REFERENCES}

[1] M.F. Ashby, Materials Selection in Mechanical Design, Butterworth-Heinemann, Oxford, 1995, pp. 48-51.

[2] A.N. SinHA, Ferrous Physical Metallurgy, Butterworth, Boston, 1989, pp. 25-26.

[3] D. Mlhal, Ph.D. Thesis, Faculty of Materials Science and Engineering, "Gh.Asachi" Technical University of lasi, 1998.

[4] D. Mihal, The Eur. J. Mech. Env. Eng. 46-3 (2001) 185 188.

[5] D. Mihal and L.G. Bujoreanu, Metall. New. Mater. Res. 2 (2001) $57-65$.

[6] D. Mihai and L.G. Bujoreanu, Metall. New. Mater. Res. (2002), to be published.

[7] V.B. JoHn, Testing of Materials, Mac Millan Education, London, 1992, pp. 30-38.

[8] J.C. Anderson, K.D. Leaver, R.D. Rawlings and J.M. AlexAnder, Materials Science, $4^{\text {th }}$ Edition, Chapman and Hall, London, 1990, pp. 212-213. 